\title{
A STUDY ON THE TOXIC EFFECTS OF CONTOF (A SYSTEMIC FUNGICIDE)ON BEHAVIOUR CHANGES AND ORGANIC CONSTITUENTS OF FRESH WATER FISH BARBUS CARNATICUS
}

\author{
A M VIBHANDIK ${ }^{1}$, R B GAIKWAD ${ }^{2} \&$ G P WANI ${ }^{3}$
}

${ }^{I}$ Swami Muktanand College of Science, Department of Zoology, Yeola, Dist. Nasik. (Maharashtra)India

${ }^{2}$ Department of Zoology, S. M. D. M. Mahavidyalaya, Kalamb, Dist. Osmanabad (Maharashtra) India

${ }^{3}$ Post graduate and Research, Department of Zoology, B.P. arts, S.M.A. Science and K.K.C. Commerce College, Chalisgaon, Dist. Jalgaon (Maharashtra) India

\begin{abstract}
Economy of our country is based on Agriculture. It provides food to big population of India. Farmers of our country always looking for different ways to increase the crop yield and for that reason, pesticides are widely used with minimum labour and efforts. All these chemical pesticides are applied in different forms and in different ways, which enters in the water bodies through rain fall. This pesticide revelationcauses toxicity in numerousnon-target organisms including fish. Fresh water teleost fish Barbuscarnaticushave been revealed to distinct concentrations of Contof for 24 hours, 48, 72 and 96 hours respectively and LC 50 concentration of Contof for Barbuscarnaticus was found to be $5.9439 \mathrm{ppm}$ for $24 \mathrm{~h}, 5.2142 \mathrm{ppm}$ for $48 \mathrm{~h}, 5.2469 \mathrm{ppm}$ for $72 \mathrm{~h}$ and $5.2516 \mathrm{ppm}$ for $96 \mathrm{~h}$. and $1 / 10^{\text {th }}$ of the corresponding LC50 values were treated as sublethalconcentrations. Fish Barbuscarnaticus exposed to sublethal concentration showed abnormal behaviour like increased opercular movements,improper swimming, loss of equilibrium, restlessness, increased secretion of mucous and rapid jerk movements were observed, which might be due to toxic effect of pesticide. The individual characters such as size and weight, sex and biological behaviour are important determination for variation in LC 50 values.

Current investigation is an endeavourdone to analyse the toxicity of the pesticide Contof with respect to biochemical constituent like protein content of target organs- Liver, kidney and muscle of fish Barbuscarnaticus. The pesticide influences not only fishes and also damage the food chain, food web and energy flow of the aquatic ecosystem. Pesticides which get into the body tissues of the fish influences the physiological activities. The fish showed severe histological changes like severe necrosis i.e. local death of cells,swelling andhypertrophy of cells, as the period of exposure goeson increasing. Similarly the protein content of the liver, muscle and kidney decreased up to $1.7 \mathrm{mg} / \mathrm{g}$, $1.7 \mathrm{mg} / \mathrm{g}$, and $2.1 \mathrm{mg} / \mathrm{g}$ respectively. Implementation of such pesticides should be stopped.
\end{abstract}

KEYWORDS: Barbuscarnaticus, Contof, Histology and Biochemistry

Received: Oct 30, 2020; Accepted: Nov 20, 2020; Published: Dec 29, 2020; Paper Id.: IJZRDEC20203

\section{INTRODUCTION}

Agriculture based economy of our country is damaged by global warming, irregular monsoon and different environmental problems. Population explosion is one of most serious problems India is facing. In order to provide food for hundred crore population of our country, farmers are now using chemical pesticides, fertilizers to increase the crop yield. All these pesticides enter ponds, rivers, dam through rain water runoff and causes water pollution. It 
is toxic and causes change in physicochemical properties of water that wasresidence to various aquatic organisms (Dondhue et al 2006; Kamble and Muly 2000; Bhalchandra et al 2001; Madhab Prasad et al 2002).

The varied water standardbadlyinfluences these organisms alsoresults in their impermanence in severe concentrations as well as seriousrevelation (Sarwar et al 2007 Sabae et al 2014). Pesticides have the possibility to be reason for bad health and environment harm. (Tamizhazhagan V 2015).Aquatic water bodies are frequently polluted with a multiple of potentially hazardous substances (Cattaglin and Fairchild 2002).

Most of the farmers are now widely using Contof. Lethal effects of pesticides are rare in nature as the organisms were revealed to less concentration that wasgenerally sublethal(Dehn and Schrif 1986). At sublethal levels behavioural modificationsleads to a reduction in the normal activity of the organism. ).Behavioural responses to aquatic pollutants were researchedin several fishes. (David et al 2002).

Fish proteins are well balanced with essential amino acids and are comparable to other proteins of animal's origin (Tont, 1977). Further fishes contains lipids especially omega fatty acids from the human nutrition point of view. The natural physiological functioning of organismsgets disturbed on exposure to toxicants stress. It induces its result first at cellular or even at molecular level. Howevereventuallyleads to physiological, pathological as well as biochemical alteration. Toxicity data for a different of pesticides likeOrganophosphate, Organochlorine, Carbamide and Pyrethroid pesticides wasoutlined in number of fish species by several authors (SapnaShrivasta et al 2002; Nisar and Yeragi 2004; Visvanathan et al 2009).Organophosphorous are highly toxic to fish and other non-target aquatic organisms and were powerful nerve poisons, since they inhibit AChE activity (Sanathkumar et al 2000; Zhang et al 2010; Srivastava et al 2010; Maniyar et al 2011).The currentanalysis is carried to assess the consequence of sublethal concentrations of Contof on behavioural, histopathological and biochemical modifications in the fish Barbus carnaticus.

\section{MATERIALS AND METHODS}

The toxicity tests were conducted as per the recommendations of APHA (1998). Fish Barbus carnaticus (approx.Wt. 100 g.) were gathered from the Girna Dam, built on Girna river in Dist: Nasik, Maharashtra as well asadopted to the lab circumstances for a duration of 15 days in a large tank of 1000 litre, formerlycleanedusing potassium permanganate along with water temperature have been $26 \pm 35^{\circ \mathrm{c}}$ and $\mathrm{pH} 7.0-7.2 \mathrm{kept}$ in aquarium.

\section{TOXICITY ASSAY}

Ten Barbus carnaticus have been retainedin a glass tank of dechlorinated tap water. The fish are managed using varying concentrations of Contof. The $1 / 10^{\text {th }}$ of the LC50 values were taken as sublethal concentrations for the 24, 48, 72 and 96 hours, respectively. To observe the biochemical as well as histopathological changes in target organs of Barbus carnaticus a group of ten individuals revealed to different sublethal concentrations of Contof for 24, 48, 72 and 96 hours, respectively. All individuals in control have been continued in pesticide free dechlorinated water in the individual tank. Throughout thetest, impermanencehas beennoted for 24, 48, 72 and 96 hours respectively. After exposure and completion of treatment, Barbus carnaticus were dissected; muscle, liver, kidney, ovary and testis were removed and fixed for routine microtechnique procedure. Sections have been split $(8 \mu)$ as well as stained with a haematoxyline and eosin.

\section{RESULTS AND DISCUSSIONS}

LC 50 concentrations of Contof for the freshwater fish Barbus carnaticus were found to be $5.9439 \mathrm{ppm}$ for $24 \mathrm{~h}, 5.2142$ 
ppm for 48h, $5.2469 \mathrm{ppm}$ for $72 \mathrm{~h}$ and $5.2516 \mathrm{ppm}$ for 96 hours. The biochemical surveys for protein from management as well asinvestigational groups of fishes of Barbus carnaticus were as indicated in Table 1. Protein content in the liver of the fish under control is $17.9126 \mathrm{mg} / \mathrm{g}$ and in the experimental fish, it is $14.7658 \mathrm{mg} / \mathrm{g}$ at $96 \mathrm{~h}$. and the value was decreased up to $5.9423 \mathrm{mg} / \mathrm{g}$ at $96 \mathrm{~h}$. Similarly the protein content of the kidney of control fish was $14.9653 \mathrm{mg} / \mathrm{g}$ at $96 \mathrm{~h}$. so it decreased up to $5.8888 \mathrm{mg} / \mathrm{g}$ at $96 \mathrm{~h}$.

It is evident from results that Contof is moderately toxic to Barbus carnaticus. The fish behaved normal in natural manner with harmonized movements. They have beencaution at the little disturbance but in the toxic environment they showed uneven erratic as well as darting swimming movements along with loss of equilibrium. Quantitative behavioural change is the most sensitive indicator of toxicant induced change in living systems. The behavioural variations were noted directly associated to complicated physiological responses and were frequently been utilized as sensitive indicator of stress (Eisler 1977). When fish exposed to pesticide they were disbalanced and showed sluggish behaviour, restlessness, increased secretion of mucous and rapid jerk movements were observed, which might be due to toxic effect of pesticide. The migration of the fish to the bottom of the glass tank following the addition of Contof clearly indicates the avoidance behaviour of the fish (Peddar and May 1985, 1986, Prashanth et al 2005).

Histological study is essential to know the damage at tissue level done by the pesticide. Histology of liver of control fish is given in (Fig. 1). The normal liver showed external structure of hepatic cells and connective tissue. Histopathology of experimental fish showed appearance of small vacuoles, degenerations of hepatocytes and necrosis of cells, proliferations of ducted cells (Fig.2). Hepatic cells are scattered and showed large vacuoles. In many places necrosis is observed in liver at 96 hours stage. All these results of liver are in agreement with those of Saxena et al; (1989).They said that Malathion is more toxic than Carbaryl in inhibition and the de novo synthesis of lipid and protein in the liver of Ophiocepphalus punctatus.

Histology of fish kidney under control (Fig. 3) showed many nephrons and each nephron consists of two parts the glomerulus and urinary tubule, normal distinct glomerulus with proximal tubule, conducting tubule with sinus appeared in connective tissue, necrosis swelling in renal tubules etc. (Fig.4). As toxic products are eliminated through the kidney, kidney is susceptible to sublethal doses of Contof. It might have caused degenerative changes in renal tubules and glomerulus i.e. necrosis in the proximal tubules and glomerulus of kidney. Degenerative alterations in epithelial cells of gathering tubules of Tilapia mossambica exposed to Fenvalerate, was outlined by Radhaiah (1985). Shrinkage of glomerulus was outlined in Nemachelius denisoni (Day) revealed to phosphomidan, Rashatwar and Ilyas (1984). Related Outcomes on fresh water teleosts were reported by Koteswara Rao (2003) and Tilak etal; (2004).

The ovary of normal Barbus carnaticusshows that it was encircledthrough an ovarian wall that wasdistinguished into an outer thin peritoneum a thicker tunica albuginea built of connective tissue, muscle fibres along with blood capillaries. The innermost layer was the germinal epithelium that joins with the tunica albuginea in many places as well as projects into the central lumen of the ovocoelom in the form of finger such asestimationsknown as ovigerous lamellae (Fig 5). The histology of experimental fish ovary showed disrupted follicular epithelial cells. Nucleolus indicated condensation of crescent formed dark granules at one side. Degeneration of epithelial cells leads to vacuolization, breakdown of germinal vesicles, and several disrupted oogonia (Fig 6). Most of the workers have shown that the fishes exposed to pesticides led to lowered steroid genesis Kapur et al; 1978. Stoppage of growth of advanced oocyte stages and hencedecreasing the amount of viable oocytes (Saxena \& Garg 1978, Yasuno et al; 1980, Mani \& Saxena 1985). The raise 
in follicular atresia has beenevident due to effect of pesticides on fish ovary. Both inhibited the development of oocytes as well asincreasedoccurrences of follicular atresia were obvious in ovary of Channa orientalis exposed to Nuvan Dimecron as have been observed in the case of certain fishes (Shukla et al; 1984, Mani \& Saxena 1985, Ghosh 1986, Singh \& Sahai 1986, Khillare \& Wagh 1987, Patwardhan \& Gaikwad 1990, Dutta et al; 1994. The histological irregularities in ovaries can be due to elements like ionizing radiations, electric current, parasitic infections andXenobiotic toxicants. Sarojini and Victor (1985) as well asusing difference of effluents and aquatic pollutants (Shukla et al; 1984 Saxena \& Garg 1978 Johnson et al ; 1988 McComic et al 1989 Kumar et al; 2000.) Nearly all related histopathological discoverieshas been outlined by Hossain et al; 2002 in the ovaries Anabas testudineus.

The histology of fish testis under control is given in (Fig.7).The normal testis showed healthy seminiferous tubules that was internally lined by tubular epithelium that providesarise to spermatocytes. Histopathology of experimental fish testis, showed disrupted seminiferous tubules and immature spermatogonia and general inflammatory response (Fig.8). Testicular inflammation has beenreported as one of the general responses in both aquatic as well as terrestrial animals revealed to environmental toxicants (Sokal et al; 1985 Ruby et al; 1986 1987. Exposure of Contof was responsible for histopathological detriment of fish testis and vacuolization of tubular cells and distortion of seminiferous tubules, enlarged interstitial and haemorrhage in inter tubular area in albino rats revealed to pesticides was outlined. Dutt and Dikshith 1973,Nigam et al; 1979 and Baronia \& Sahai 1993 Katti \& Sathyanesan 1985 observed exposure dependent on concentration mediated changes in testis of C. batrachus treated with lead . Kinnberg et al; 2000 was alsoreported concentration dependant consequences on nonylphenol on testicular structure of the fish Xiphophorus maculates and Zusthi 2005 noted that the consequence of fenthion on experiments of Glassogobious giuris. They noteddecrease in size with spermatids and sperms in degenerating condition.

Proteins are complex substances with high molecular weight forming structural frame work of body. Proteins are useful for transport and storage. Carrier proteins transport many small molecules and ions. Proteins supply the amino acids needed for the growth, repair and general maintenance of the structural and catalytic cycle of the metabolism. When compared to the experimental groups treated with Contof, protein level is decreased by $1.7 \mathrm{mg} / \mathrm{g}$ at $96 \mathrm{~h}$. Similar results have been reported in Sarotherodon mossambicus (Ghosh \& Chatterjee 1985)Cyprinus carpio (Malla Reddy \& Bashamohideen 1991) and Glassogobius giuris (Sreenivas et al; 2005). The decrement in the protein content with increased exposure period suggests that high protein hydrolysis that could be due to pesticide interfering and impairment as well as lowering of protein synthesis in fish muscle. (Ghosh \& Chatterjee 1985).Malla Reddy and Bashamohideen 1988 reported that the portease activity can increase protein breakdown in the tissue of the fish exposed to pesticide Fenvalerate. The treated fish drew their energy from body proteins by the process of gluconeogenesis (Sreenivasa, 2002). Proteins decreased due to the tissue protein under goes proteolysis. The result in the production of free amino acids which are used in TCA cycle for energy production under stresses (Muthukumaravel et al, 2013). There are similar reports of effects of toxicants on total protein in other fishes by Veeraiah et al, 2013, Nagaraju 2013) In the present study the result clearly showed that there was a decreased amount of protein content to resist the toxic effect of pesticide. It is to provide immediately energy to the fighting elements of the body and protect all systems of the body from harmful effect of the pesticide. Muscle rich in proteins forms mechanical tissues intended for mobility and do not participate in metabolism. Liver being the centre for various metabolisms also rich in proteins. In all the tissues of exposed fish the protein content was found to be reduced. Toxicants affect the vital organs like liver, kidney, muscle, and gonads. Decrease in the protein content may be due to metabolic utilization of the ketoacids to gluconeogenesis pathway for the synthesis of glucose or due 
to directing the free amino acids for the synthesis of proteins or for the maintenance of osmo and ionic regulation (Schmidt Nielson, 1975). It could be due to the production of heat shock proteins or destructive free radicles. A gradual increase in the damage was noticed and the severe histological lesions caused by physiological and biochemical disturbances in fish.

Table 1: Effect of long term exposure of sublethal concentrations of Contof on protein content of liver, muscle, and kidney of Barbus carnaticus smg/g dry weight

\begin{tabular}{|c|c|c|c|c|c|c|}
\hline \multirow[t]{4}{*}{ Organ } & \multirow[t]{4}{*}{ Control } & \multicolumn{5}{|c|}{ Experimental } \\
\hline & & & $24 h$ & $48 \mathrm{~h}$ & $72 \mathrm{~h}$ & 96h \\
\hline & & L.C.50 & 5.9439 ppm & $5.2142 \mathrm{ppm}$ & $5.2469 \mathrm{ppm}$ & 5.2516ppm \\
\hline & & SublethlConc. & 0.594 ppm & 0.521 ppm & 0.524 ppm & $5.251 \mathrm{ppm}$ \\
\hline \multirow[t]{4}{*}{ Liver } & $\begin{array}{c}17.9126 \pm \\
0.743\end{array}$ & & $\begin{array}{c}16.6591 \pm \\
0.845\end{array}$ & $\begin{array}{c}15.8709 \pm \\
0.825\end{array}$ & $\begin{array}{c}15.1892 \pm \\
0.719\end{array}$ & $\begin{array}{c}14.7658 \pm \\
0.698\end{array}$ \\
\hline & & $\%$ & -6.995 & -11.398 & -15.201 & -17.567 \\
\hline & & $\mathrm{T}$ & 3.707 & 2.6460 & 8.352 & 9.7635 \\
\hline & & $\mathrm{P}$ & $\mathrm{P}<0.01$ & $\mathrm{P}<0.01$ & $\mathrm{P}<0.01$ & $\mathrm{P}<01$ \\
\hline \multirow[t]{4}{*}{ Muscle } & $\begin{array}{c}15.12582 \pm \\
0.681\end{array}$ & & $\begin{array}{c}11.9309 \pm \\
0.599\end{array}$ & $\begin{array}{c}10.6398 \pm \\
0.487\end{array}$ & $\begin{array}{c}9.6843 \pm \\
0.469\end{array}$ & $\begin{array}{c}9.1835 \pm \\
0.451\end{array}$ \\
\hline & & $\%$ & -21.293 & -29.803 & -35.111 & -33.415 \\
\hline & & $\mathrm{T}$ & 10.465 & 11.865 & 13.341 & 13.832 \\
\hline & & $\mathrm{P}$ & $\mathrm{p}<0.01$ & $\mathrm{p}<0.01$ & $\mathrm{p}<0.01$ & $\mathrm{p}<0.01$ \\
\hline \multirow[t]{4}{*}{ Kidney } & $\begin{array}{c}14.9653 \pm \\
0.513\end{array}$ & & $\begin{array}{c}11.2980 \pm \\
0.481\end{array}$ & $\begin{array}{c}10.9064 \pm \\
0.466\end{array}$ & $\begin{array}{c}9.2649 \pm \\
0.412\end{array}$ & $\begin{array}{c}9.0765 \pm \\
0.412\end{array}$ \\
\hline & & $\%$ & -24.602 & -27.122 & -38.090 & -39.349 \\
\hline & & $\mathrm{T}$ & 15.742 & 16.861 & 18.643 & 18.854 \\
\hline & & $\mathrm{P}$ & $\mathrm{P}<0.01$ & $\mathrm{P}<0.01$ & $\mathrm{P}<0.01$ & $\mathrm{P}<0.01$ \\
\hline
\end{tabular}

The above values indicate Mean \pm S.D.

Many workers have reported the toxicity induced by insecticides on various organs of fish (Ishihara\& Tamura 1967, Bhattacharya \& Mukherjee 1975, Dubale \& Awasthi 1982).Liver and kidney being the worst affected organs by toxicants. Histopathological lesions have been observed by Anees (1975) in the kidney of Channa punctatus, exposed to Malathion.

The present investigation evidenced that Contof is toxic and had profound effect on the behaviour and histology of liver, kidney, ovary and testis of Barbus carnaticus in sublethal concentrations. 

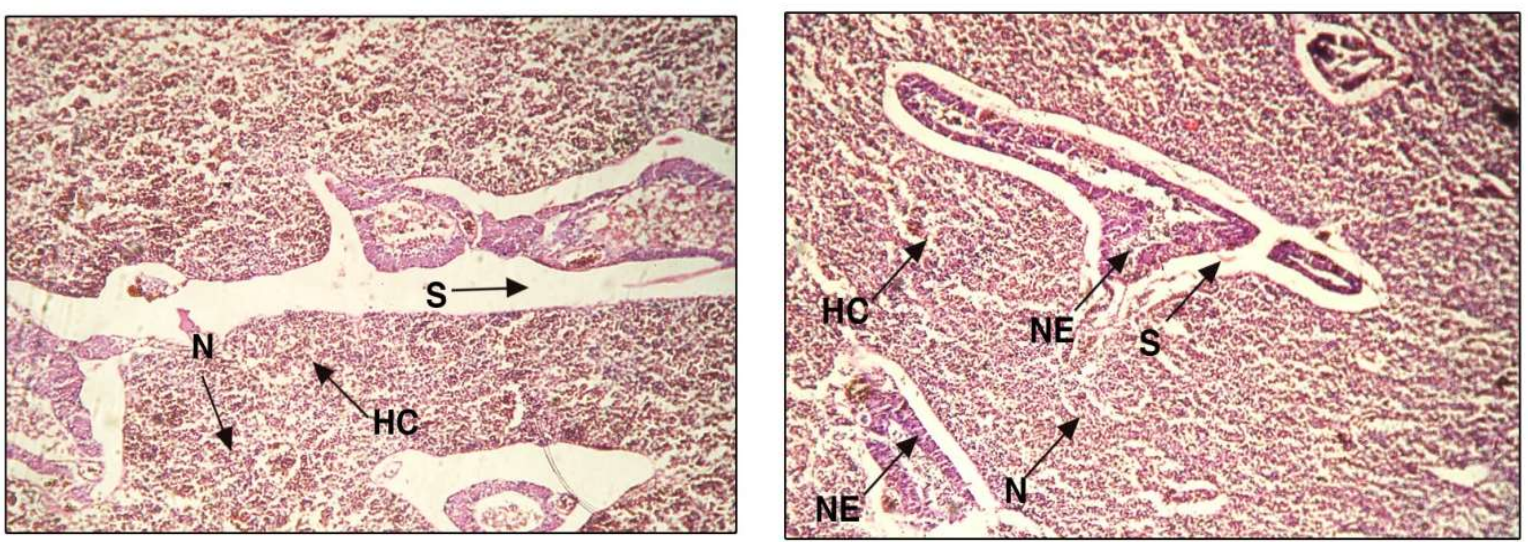

Figure 1: T.S. of liver from B.carnaticus (Control).Figure 2: T.S. of liver from B.carnaticus (Exposed to Contof for 96h) Hc- Hepatocyte, N-Nucleus, NC-Nucleolus, S-Sinuside HC-hepatocyte, S- sinuside, N- nucleus
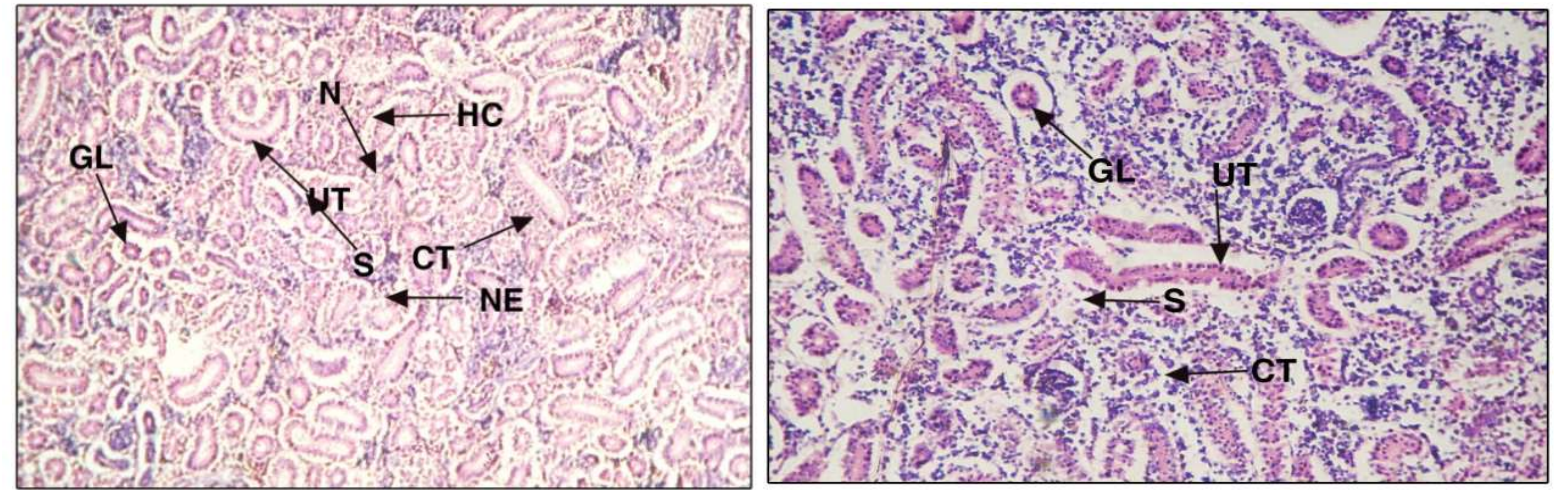

Figure 3: T.S. of kidney from B.carnaticus (Control).Figure 4: T.S. of kidney from B.carnaticus (Exposed to GL-Glomerulus, UT-Uriniferous Tubule, S-SinusContof for 96h). GL-Glomerulus, UT-Uriniferous Tubule, S-Sinus.
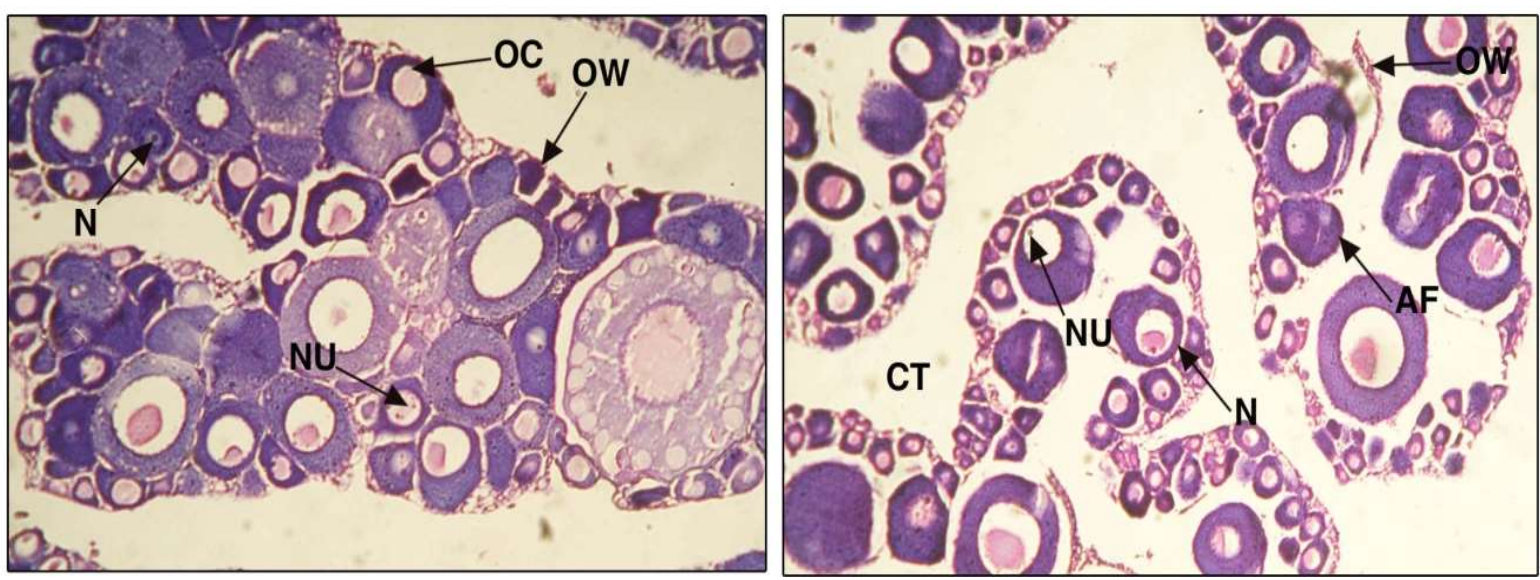

Figure 5: T.S. of ovary from B.carnaticus (Control). Figure 6: T.S. of ovary from B.carnaticus (Exposed to Contof for 96 h).OC-Oocyte, NU-Nucleolus, N-Nucleus, OC-Oocyte, NU-Nucleolus, N-Nucleus,

OW-Ovarian Wall. OW-Ovarian Wall, AF-Atretic Follicle. 

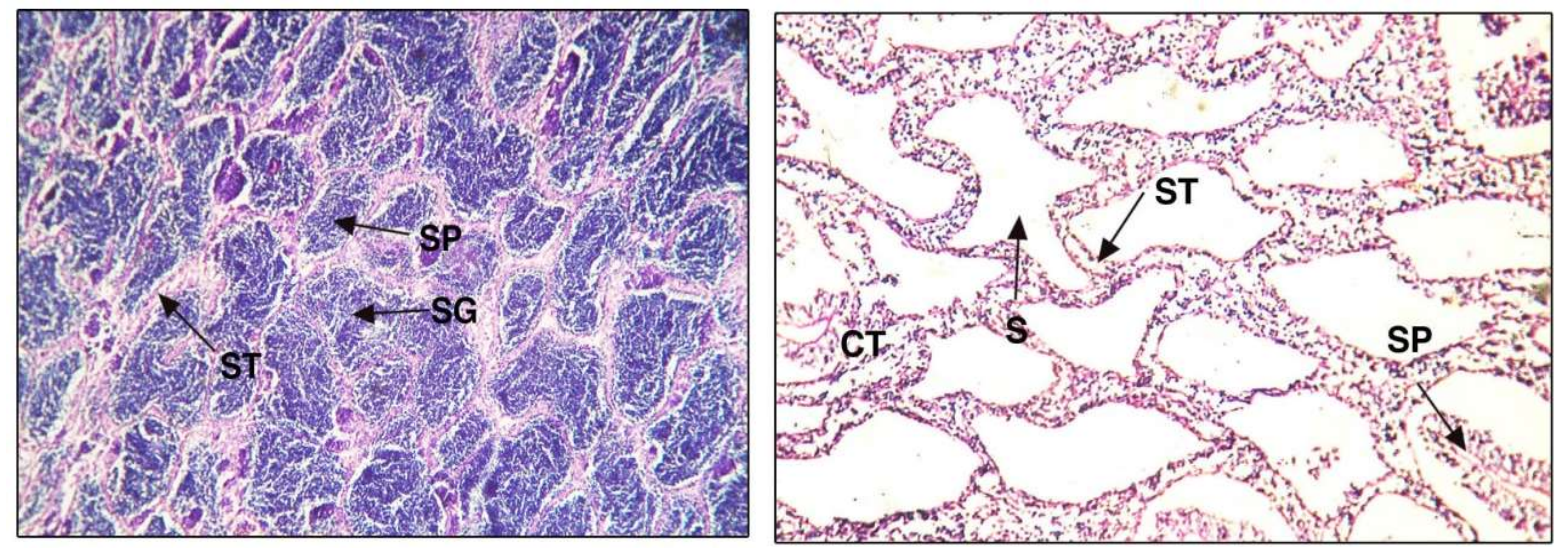

Figure 7: T.S.oftestis from B.carnaticus (control). Figure 8: T.S.of testis from B.carnaticus (Exposed to Contof for 96 h).

SL-Seminiferous Lobule, SG- Spernatogonia, SL-Seminiferous Lobule, SG- Spernatogonia, SP- Spermatids.

\section{SP- Spermatids}

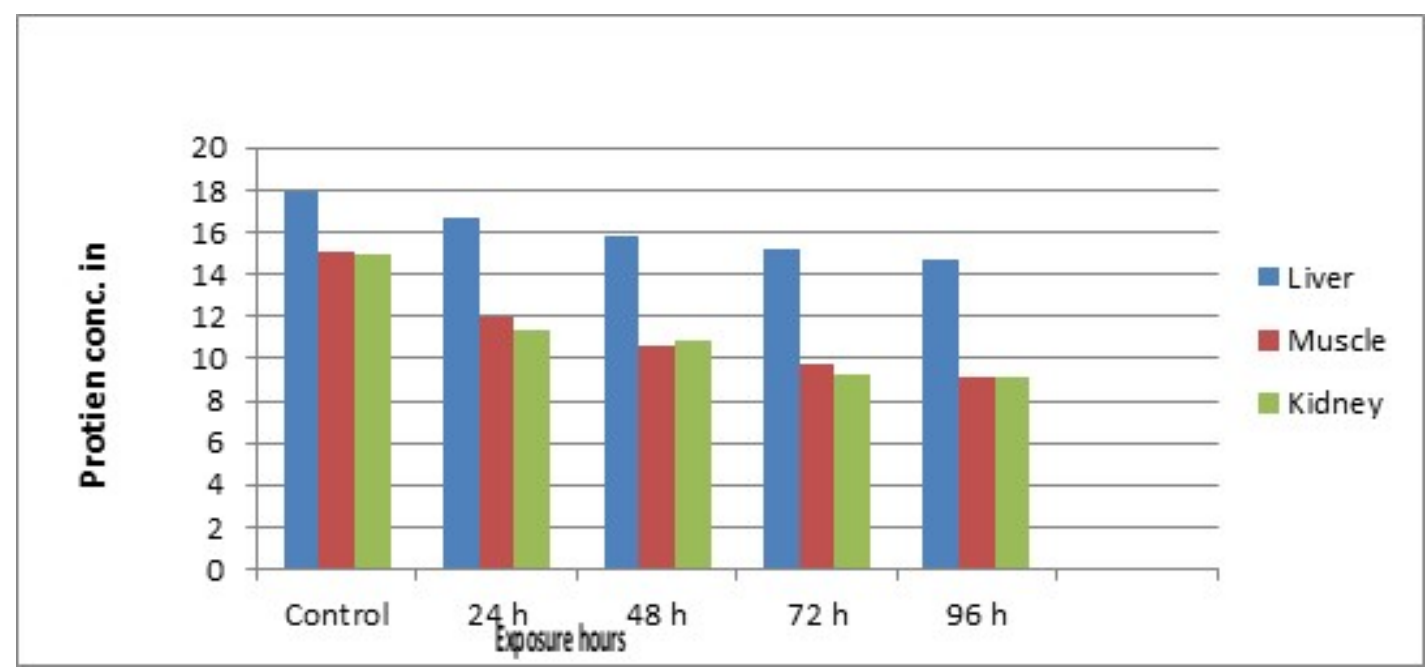

Graph showing changes in protein content in Kidney, Muscle and Liver of B. Carnaticus after exposure to Contaf.

\section{REFERENCES}

1. Balakrishnan, V. I. D. Y. A., K. P. Asifa, and K. C. Chitra. "Genotoxic potential of nonylphenol in freshwater fish, Oreochromis mossambicus." International Journal of Applied and Natural Sciences 3.2 (2014): 81-88.

2. REHMAN, MUNEEB U., et al. "Endosulfan, a global pesticide: a review of its toxicity on various aspects of fish biology." Int. J. Gen. Med. Pharm. 5 (2016): 17-26.

3. Meziane, M. A. L. I. K. A., and H. A. L. I. M. A. Goumri. "The antimicrobial effect of extracts of Melia azedarach on some pathogenic microorganisms." Int. J. Appl. Nat. Sci 3 (2014): 173-180.

4. Sarkar, Angshuman, Geethanjali Ravindran, and Vishnuvardhan Krishnamurthy. "A brief review on the effect of cadmium toxicity: from cellular to organ level." Int J Biotechnol Res 3.1 (2013): 17-36. 

